\title{
Keterampilan Berpikir (Mind Skills) Pada Proses Konseling: Kajian Dalam Perkembangan Kognitif Neurosains
}

\author{
Khilman Rofi Azmi \\ IAIN Kudus, Jawa Tengah, Indonesia \\ rofiazmi@live.com
}

\begin{abstract}
Abstrak
Perkembangan dalam keilmuan psikologi dan bimbingan konseling adalah indikator berkembangnya kajian keilmuan yang signifikan. Salah satu issue/problem konselor terbesar adalah praktik konseling. Konseling sebagai "jantung" dari tugas dan tanggungjawab konselor memiliki tiga keterampilan dasar kebutuhan, yaitu keterampilan komunikasi, keterampilan bertindak, dan keterampilan berpikir. Keterampilan berpikir adalah proses mental sentral dengan enam aspek yang menciptakan: (1) aturan; (2) persepsi; (3) Self Talk; (4) gambar visual; (5) penjelasan; (6) harapan. Keterampilan berpikir dibuktikan oleh peneliti untuk meningkatkan kualitas konseling dan fokus untuk mengelola pikiran superconscious. Tulisan ini mencoba menghubungkan antara keterampilan berpikir dengan aktivitas otak dalam perspektif ilmu saraf. Proses keterampilan berpikir berhubungan dengan neuroscientific notions dari kontrol kognitif kemudian melewati sintesis di mana subfraksi kortikal prefrontal dorsolateral dan anterior berinteraksi dengan korteks interoceptive (cingulate dan insula) untuk meningkatkan kecakapan berpikir. Artikel ini menggunakan kajian studi literatur sebagai metode penelitian dengan mengeksplorasi dan mengkaji beberapa literatur: buku, jurnal, disertasi, e-book, dan beberapa kasus yang terjadi di masyarakat.

Kata kunci: keterampilan berpikir, cognitive neuroscience, development
\end{abstract}




\title{
Keterampilan Berpikir (Mind Skills) Pada Proses Konseling: ...
}

\begin{abstract}
The development in psychological science and counseling are indicators of significant science development. One of the biggest counselor issues/problems is counseling practice. Counseling as the "heart" of the duties and responsibilities of the counselor has three basic skills needs, namely communication skills, acting skills, and thinking skills. Thinking skills are central mental processes with six aspects that create: (1) rules; (2) perceptions; (3) self talk; (4) visual images; (5) explanations; (6) expectations. Thinking skills are proven by researchers to improve the quality of counseling and focus on managing the superconscious mind. This paper tries to connect between thinking skills and brain activity in a neuroscience perspective. The process of thinking skills related to neuroscientific notions of cognitive control then passes synthesis where the dorsolateral and anterior prefrontal cortical subfraction interacts with the interoceptive cortex (cingulate and insula) to improve thinking skills. This article uses a study of literature studies as a research method by exploring and reviewing some literature: books, journals, dissertations, e-books, and some cases that occur in the community.

Keywords: thinking skills, cognitive neuroscience, development
\end{abstract}

\section{A. Pendahuluan}

Layanan Bimbingan dan Konseling merupakan bagian integral dari kegiatan pendidikan di sekolah. Sebagai layanan profesional, kegiatan layanan Bimbingan dan Konseling (BK) tidak dapat dilakukan sembarangan, namun harus berangkat dan berpijak dari suatu landasan kokoh, yang didasarkan pada hasil-hasil pemikiran dan penelitian yang mendalam. Melalui pijakan yang jelas dan kokoh diharapkan pengembangan layanan BK semakin mantap dan bisa dipertanggungjawabkan serta mampu memberikan manfaat besar bagi kehidupan, khususnya bagi konseli. Salah satu layanan yang paling vital dalam penyelenggaran BK adalah layanan konseling. Gladding (2009:6), mengungkapkan bahwa "konseling merupakan aplikasi dari kesehatan mental, prinsip-prinsip psikologis dan 
perkembangan manusia termasuk di dalamnya adanya intervensi kognitif, afektif dan perilaku, strategi yang bertujuan untuk mencapai kesehatan, pertumbuhan pribadi atau perkembangan karier serta hal-hal yang bersifat patologis". Konseling merupakan layanan profesional yang selama ini dirasa belum dilakukan oleh konselor secara optimal. Jones (2003) mengungkapkan adanya kesenjangan antara teori yang diajarkan pada rumpun mata kuliah konseling dengan praktik di lapangan. Konselor mengaku sudah memahami berbagai pendekatan konseling yang diajarkan, namun ketika dalam praktik proses konseling, konselor sering kali menemui hambatan yang lebih bersifat kognitif dan afektif. Keterampilan berpikir (mind skills) membantu \& menuntun konselor dalam melaksanakan setiap langkah dalam proses konseling dan membantu dalam setiap keputusan yang dibuat oleh konselor selama proses konseling (Azmi, 2015).

Penelitian-penelitian yang dimuat oleh (Hidayah, 2009,2012) telah menunjukkan urgensi mind skills yang tinggi dalam proses konseling. Seorang konselor ketika dalam setting konseling akan sangat sering memutuskan hal-hal penting baik terkait dengan konseli maupun terkait dengan diri konselor sendiri. Namun kerap kali konselor tidak menyadari bahwa pada dirinya mampu mengontrol dan mengendalikan setiap pikiran membantu yang muncul selama konseling bahkan dalam kondisi yang sulit sekalipun sehingga banyak konselor yang melakukan konseling namun hasilnya tidak sesuai dengan ekspektasinya. Mind skills akan membantu konselor dalam menentukan segala keputusan yang membantu dalam proses konseling. Perkembangan penelitian tentang mind skills pada seting layanan konseling di Indonesia dianggap belum terlalu banyak, beberapa penelitian tentang mind skills antara lain (Nur Hidayah, 2009, 2012); (Carolina, 2012); (Simon, 2011); (Naning, 2013); (Azmi, 2015) dan beberapa penulis lainnya.

Artikel ini mencoba mengkaji mind skills dari sudut pandang keilmuan neuroscience. Mind skills dalam gambaran aktivitas otak yang kemudian ditujukan untuk menguatkan landasan teori serta bukti efektivitas penggunaan mind skills dalam proses konseling. 
Metodologi penelitian ini menggunakan penelitian berbasis studi literatur/studi pustaka yang dilakukan dengan mengkaji dan menggali berbagai teori dan praksis melalui literatur mulai dari buku, jurnal ilmiah, disertasi, e-book, internet dan berbagai data serta fakta yang ada dalam masyarakat, khususnya di sekolah.

\section{B. Pembahasan}

\section{Keterampilan Berpikir (Mind Skills)}

Istilah mind skills, yang oleh Raka Joni disebut sebagai mind competence merupakan ketangkasan merespons secara kontekstual, yang bermuara pada problem solving dalam konseling (Joni, 2008). Senada dengan hal tersebut, Jones (2005), menjelaskan bahwa mind skills adalah serangkaian tindakan yang harus dilakukan oleh seorang konselor profesional supaya konseling yang dilakukan dapat berlangsung secara tepat dan efektif. Dengan proses tersebut, seorang konselor dapat meninjau kembali tindakan-tindakan yang telah dilakukan dan melakukan refleksi tertentu pada tindakan berikutnya secara berkelanjutan yang tersimpan dalam kognisi konselor yang bersangkutan sebagai pengalaman atau pengetahuan tentang cara melakukan konseling.

Secara lebih luas, keterampilan berpikir setara dengan istilah (term) keterampilan metakognitif, yaitu keterampilan untuk memikirkan apa yang kita pikirkan (thinking about thinking). Konsep metakognitif biasanya dikonsepsikan sebagai seperangkat kompetensi yang saling berhubungan dalam belajar, berpikir, dan termasuk di dalamnya membutuhkan keterampilan untuk mendengarkan aktif, berpikir kritis, penilaian yang reflektif, penyelesaian masalah, dan pengambilan keputusan (Dawson, 2008:3).

Ketika konselor mampu menggunakan keterampilan berpikir dalam menyelenggarakan layanan konseling, ada beberapa keuntungan yang akan mereka peroleh. Keuntungan tersebut adalah sebagai berikut: (1) Konselor dapat menyadari dan memahami bahwa mereka memiliki kemampuan untuk berpikir dengan kesadaran super (super-conscious thinking) yang dapat dikembangkannya menjadi lebih baik; (2) Konselor dapat berpikir dengan lebih efisien, memikirkan untuk apa mereka berpikir 
(thinking about thinking) jika mereka mampu melihat proses mental yang terjadi dalam setiap keahlian yang mereka miliki, sehingga mereka memiliki kesempatan untuk menyadari, mengukur, dan mengontrol keterampilan berpikir (mind skills) yang dimilikinya; dan (3) Konselor dapat melatih keterampilan berpikir (mind skills) yang dimilikinya sebaik mereka melatih keterampilan komunikasi atau penguasaan teori-teori konseling yang ada, sehingga pada akhirnya mereka dapat mengembangkan keterampilan konseling yang mereka miliki dengan lebih tepat dan efektif.

Jones (2005) mendeskripsikan bahwa terdapat enam komponen keterampilan berpikir (mind skills) yang seharusnya dimiliki oleh konselor, sebagai berikut:

\section{a. Menciptakan peraturan yang membantu}

Peraturan diartikan sebagai hal yang 'boleh' dan 'tidak boleh' dilakukan oleh seseorang dalam hidupnya. Peraturan mengenai boleh dan tidak boleh ini diciptakan oleh individu sendiri atau oleh pengaruh lingkungan. Jones (2005), menjelaskan bahwa menciptakan peraturan yang membantu adalah menciptakan peraturan yang bersifat realistis dan preferensial, menggantikan peraturan-peraturan yang bersifat menuntut atau absolut. Peraturan preferensial bersifat luwes dan memberikan alternatif pilihan, jauh dari tuntutan yang bersifat tidak rasional. Berbeda dengan peraturan yang menuntut atau absolut yang berarti bahwa peraturan tersebut bersifat kaku, mutlak, dan tidak memiliki pilihan lain kecuali dijalankan.

\section{b. Menciptakan persepsi yang membantu}

Persepsi diartikan sebagai tingkat akurasi atau ketepatan seseorang dalam menyadari dan menilai dirinya sendiri, orang lain, dan situasi. Konsep persepsi ditekankan pada konsep tentang pemikirian proporsional. Hal ini termasuk di dalamnya menguji kenyataan tentang persepsi diri sendiri, orang lain, dan situasi (Jones, 2005). Menciptakan persepsi yang membantu berfokus pada bagaimana tingkat akurasi seseorang menyadari dirinya sendiri dibandingkan dengan menyadari orang lain. Seberapa tinggi seseorang mampu menilai dirinya sendiri dibandingkan dengan menilai orang lain. 


\section{c. Menciptakan wicara diri yang membantu}

Percakapan yang terjadi dalam konseling, setidaknya terdiri dari tiga hal, yaitu: (1) percakapan umum antara konselor dengan konseli; (2) percakapan dalam diri konseli; dan (3) percakapan dalam diri konselor. Percakapan diri atau wicara diri inilah yang melibatkan proses mental yang termasuk ke dalam keterampilan berpikir (mind skills) konselor. Semua proses berpikir verbal termasuk ke dalam jenis wicara diri. Wicara diri dalam proses konseling ditekankan pada bagaimana memfokuskan diri untuk mengelola wicara diri yang ada dalam kepala konselor, sehingga konselor dapat menyelenggarakan konseling tanpa lepas arah (Jones, 2005).

Mind skills dalam konseling menekankan wicara diri atau selftalk untuk konselor dengan tujuan supaya konselor mampu menginstruksi dirinya sendiri. Apa yang harus dipikirkannya pada awal, proses, dan akhir layanan konseling. Bagaimana konselor harus menginstruksi dirinya sendiri agar menjalankan konseling dengan tepat.

\section{d. Menciptakan citra visual yang membantu}

Ketika mengalami perasaan atau sensasi yang bersifat signifikan, seseorang biasanya menggambarkan apa yang mereka rasakan dalam pikiran. Bisa jadi, apa yang diceritakan oleh orang lain juga direspons dengan menggambarkannya dalam kepala menggunakan gambar-gambar piktoral tertentu. Semakin baik seseorang terlibat dalam apa yang diceritakan oleh orang lain, maka semakin baik pula mereka menggambarkan hal tersebut di dalam kepala.

Sebagaimana self-talk, citra visual atau imajinasi visual yang dimiliki oleh seseorang bisa bersifat negatif atau positif. Sehingga keduanya seringkali muncul secara bersamaan. Konselor hendaknya dapat menggambarkan secara visual dalam kepala apa yang diceritakan oleh konselinya sehingga dia mampu membaca dengan tepat bagaimana alur pikir konseli yang sedang dihadapinya. Dimensi lain yang harus dilakukan oleh konselor adalah menghilangkan gambaran piktoral negatif lain yang dianggap tidak perlu, sehingga tidak mengganggu jalannya konseling. 


\section{e. Menciptakan penjelasan yang membantu}

Penjelasan adalah alasan-alasan yang individu berikan kepada diri mereka sendiri untuk segala sesuatu yang terjadi. Penjelasan-penjelasan itu dapat mempengaruhi bagaimana mereka berpikir tentang masa lalu, sekarang, dan masa depan mereka. Lebih lanjut, penjelasan akan mempengaruhi bagaimana perasaan, reaksi fisik, dan tindakan dari seseorang. Mind skills mengeksplorasi kemampuan konselor untuk bisa menciptakan penjelasan yang membantu. Penjelasan yang dimaksudkan adalah penjelasan dari permasalahan yang dihadapinya, yang dibawa oleh konselinya, serta penjelasan tentang konseli. Mind skills membawa konselor memberikan penjelasan kepada dirinya sendiri untuk apa dia membantu konselinya (Jones, 2005).

\section{f. Menciptakan pengharapan yang membantu}

Manusia memprediksikan apa yang akan terjadi di masa depan, sehingga mereka dapat mempengaruhi dan mengontrolnya. Sebagai akibat, manusia perlu menciptakan pengharapan tentang konsekuensi komunikasi dan tingkah laku. Bagaimana pengharapan mereka akan masa yang akan datang, hal tersebut yang akan mempengaruhi perasaan mereka sendiri, perasaan orang lain, reaksi fisik, pendapat, dan kemampuan mereka berkomunikasi dengan orang lain. Dalam keterampilan konseling, menciptakan pengharapan yang membantu berarti bahwa konselor menciptakan pengharapanpengharapan yang bersifat realistik tentang tingkat kemampuannya sendiri untuk mengatasi situasi dan orang-orang sulit.

\section{Mind Skills dan Perkembangan Keilmuan Neuroscience}

Pemikiran awal Jones (2008) tentang kemampuan konselor dalam mengatur pikirannya sendiri (super-conscious thinking) telah menarik para ilmuwan dalam meneliti lebih jauh tentang hubungan antara mind skills dengan aktivitas otak yang menyertainya.

Gambaran aktivitas otak tersebut membantu para konselor mengenali serta memahami perbedaan ketika memunculkan mind skills yang membantu atau tidak membantu.

Aktivitas didalam otak konselor selama melakukan konseling dapat merujuk pada Blakemore (2013) yang menyatakan bahwa 
salah satu bagian otak yang sangat berhubungan dengan kognisi sosial/social cognition dapat digambarkan melalui functional MRI (Magnetic Resonance Imaging). Melalui MRI, konselor yang sedang memikirkan orang lain, bertatap muka, berkomunikasi, merasakan dan memikirkan perasaan orang lain telah menunjukkan bagian otak yang lebih aktif dibandingkan dengan bagian otak lainnya yakni medial prefrontal cortex dan dua bagian lain dalam lobus temporal seperti posterior-superior temporal sulcus dan anterior temporal cortex.

Sedangkan kajian tentang neuroscience yang berhubungan dengan mind skills/ meta kognitif cukup populer dan telah mencapai puncak penemuan terbesar yang dilakukan Shimammura pada tahun 2008-2010. Model eksperimen yang dilakukan adalah seperti gambar berikut:

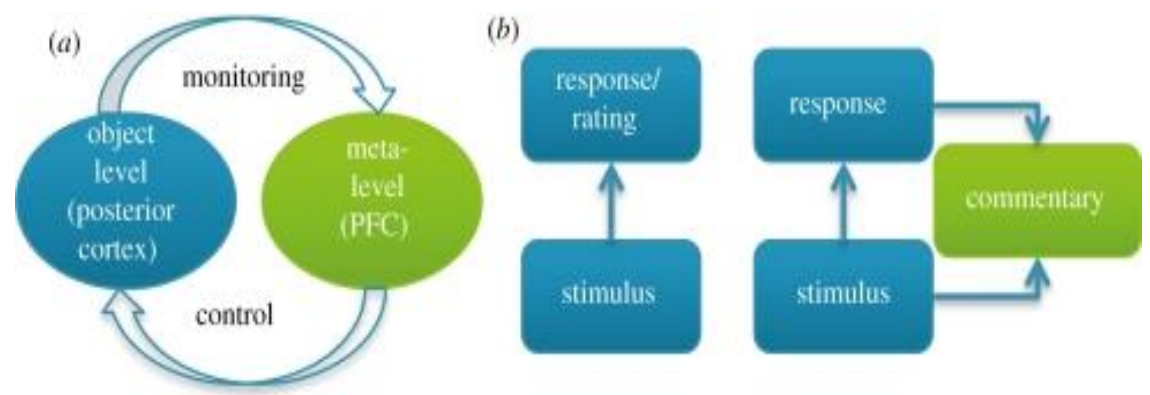

Gambar 1: Skema yang diadaptasi Shimamura (2008) menerangkan (a) model psikologi kognitif dari metakognisi yang dapat dipetakan dalam proses otak (b) panel kiri menunjukkan tanpa mindskills dan panel kanan dengan memunculkan mindskills dan berujung pada komentar, keputusan dan pemecahan masalah

Lebih rinci, penemuan hubungan antara mind skills/ metakognitif dengan gambaran aktivitas otak menunjukkan hasil bahwa ketika proses mind skills dimunculkan dan dikontrol oleh kognisi, maka terdapat interaksi yang kuat antara dorsolateral dan anterior prefrontal cortical subregions dengan interoceptive cortices (cingulate and insula) (Fleming \& Dolan, 2012). Seperti yang telah diketahui tentang fungsi bagian otak selama ini, bahwa korteks (cortex/cortical) merupakan salah satu bagian otak yang mengatur 
dan memproses pemikiran manusia, di kortekslah proses awal dalam mengelola mind skills dilakukan (Johson, 2005).

Interoceptive cortices (cingulate and insula) merupakan bagian otak yang terletak diantara lobus temporal dengan lobus parietal. Bagian ini memiliki tugas utama untuk menghubungkan antara pengalaman emosi, proses untuk merasa, kontrol untuk respon motorik serta perilaku interpersonal. Fungsi Interoceptive cortices (cingulate and insula) antara lain adalah pengambilan keputusan, kecemasan, emosi sosial dan homeostatis.

(a)

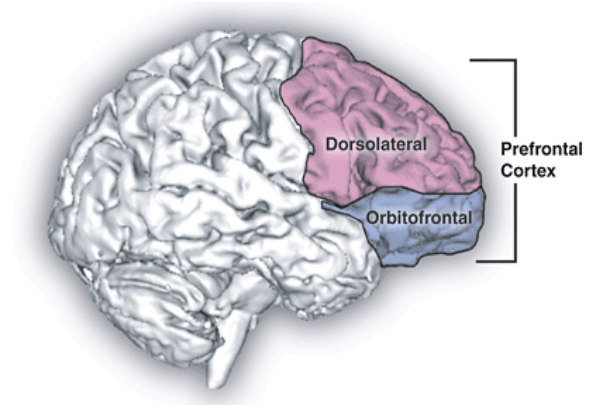

(b)

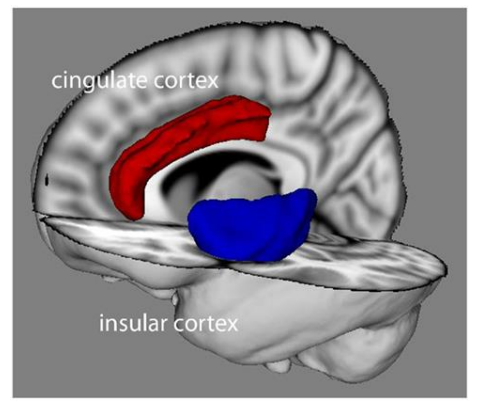

Gambar 2 : bagian otak (a) prefrontal cortex; dan (b) insular dan cingulate cortex (sumber: wikipedia \& frontiersin)

Interaksi yang kuat antara dorsolateral dan anterior prefrontal cortical subregions dengan interoceptive cortices (cingulate and insula) merupakan efek dimunculkannya mind skills. Interaksi yang semakin kuat menandakan seringnya individu dalam mengasah keterampilan berpikirnya. Dalam gambaran lebih lengkap tentang proses otak dalam memunculkan mind skills/ metakognisi dan berakhir dengan pengambilan keputusan adalah sebagai berikut: 


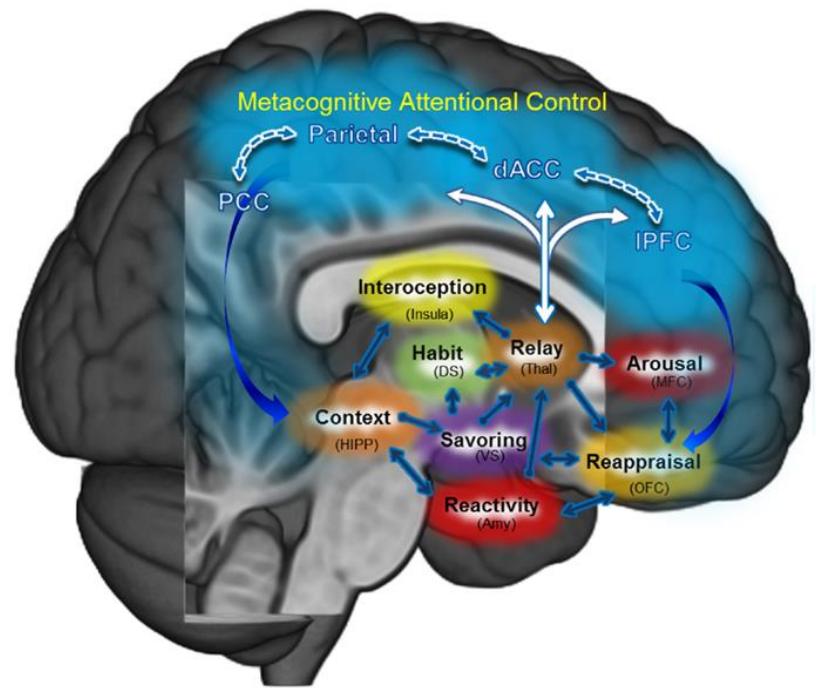

Gambar 3: proses kontrol otak terhadap metakognisi (sumber: frontiersin)

\section{Simpulan}

Keterampilan berpikir/ mind skills merupakan salah satu keterampilan yang harus dimiliki oleh konselor dalam kaitan dengan pemberian layanan konseling. Mind skills terbukti membantu konselor dalam mengatur setiap pemikiran yang muncul sebelum, selama dan sesudah proses konseling. Pemikiran yang terjawantahkan dalam 6 aspek mind skills tersebut antara lain (1) peraturan yang membantu; (2) persepsi yang membantu; (3)wicara diri yang membantu; (4) citra visual yang membantu; (5)penjelasan yang membantu; (6) pengharapan yang membantu. Persepektif ilmu neuroscience telah menguatkan kajian keilmuan tentang mind skills. Hal tersebut telah dikuatkan dengan beberapa penemuan tentang aktivitas otak berkaitan dengan proses otak yang menghasilkan temuan bahwa ketika proses mind skills dimunculkan dan dikontrol oleh kognisi, maka terdapat interaksi yang kuat antara dorsolateral dan anterior prefrontal cortical subregions dengan interoceptive cortices (cingulate and insula).

Rekomendasi dari paparan artikel ini adalah kajian lebih mendalam tentang proses dan usaha otak dalam memunculkan mind skills yang membantu dengan mind skills yang tidak membantu. Perlu 
Khilman Rofi Azmi

melakukan eksperimen dengan bantuan scan otak baik MRI maupun EEG untuk melihat pengaruh antara mind skills yang membantu dengan mind skills yang tidak membantu. 
Keterampilan Berpikir (Mind Skills) Pada Proses Konseling: ...

\section{Daftar Pustaka}

Azmi. 2015. Pengembangan Panduan Pelatihan Mind Skills Dalam Konseling Dengan Model Experiential Learning Untuk Mahasiswa Bimbingan Dan Konseling Universitas Negeri Malang. Skripsi. Tidak dipublikasikan. Malang: Universitas Negeri Malang

Blakemore. 2013. Thinking: The new science of decision making, problem solving, and prediction (The Adolescent Brain). New York: Harper Perennial

Dawson, T.L. 2008. Metacognition and Learning in Adulthood. Northampton

Fleming \& Dolan. 2012. The neural basis of metacognitive ability. Journal of Medicine, May 19; 367(1594): 1338-1349. US National Library of Medicine National Institutes of Health

Gladding, S. 2009. Keterampilan dalam Konseling. Jakarta: Pustaka Belajar

Hidayah, N. 2009. Process-Audit dalam Penyelenggaraan Pendidikan Akademik S1 Bimbingan dan Konseling. Disertasi. Tidak Dipublikasikan. Malang: PPS Universitas Negeri Malang

Hidayah, N. 2012. Penerapan Model Pembelajaran Berbasis Pengalaman untuk Mengembangkan Mind Competence Calon Konselor. Laporan penelitian. Tidak dipublikasikan. Malang: Lembaga Penelitian dan Pengabdian kepada masyarakat UM

Johnson, M. 2005. Developmental Cognitive Neurroscience: 2nd edition.Victoria :Blackwell Publishing

Jones, R.N. 2003. Basic counseling skills: A Helper's Manual. London: Sage Publications

Jones, R.N. 2005. Introduction to counseling skill. London: Sage Publications

Joni, T.R. 2008. Resureksi Pendidikan Profesional Guru. Malang:LP3 Univeristas Negeri Malang

Joni, T.R, dkk. 2008. Penajaman Keterampilan Konseling, Malang: Program Pascasarjana Universitas Negeri Malang. Tidak dipublikasikan

Naning, R. 2012. Internalisasi Keterampilan Berfikir pada Mahasiswa Bimbingan dan Konseling Universitas Negeri Malang. Tesis. Tidak Dipublikasikan. Malang: PPS Universitas Negeri Malang 
Radjah, C. 2012. Metakognisi Konselor dalam Kegiatan Layanan Konseling di Sekolah,. Desertasi. Tidak Dipublikasikan. Malang: PPS Universitas Negeri Malang

Shimamura A. P. 2008. A neurocognitive approach to metacognitive monitoring and control. In Handbook of memory and metamemory: essays in honor of Thomas $0 . \quad$ Nelson (eds Dunlosky J., Bjork R., editors. ), pp. 373-390 New York, NY: Psychology

Simon, M. 2008. Penerapan Model Experiential Learning sebagai Strategi untuk Meningkatkan Kemampuan Coping Self Talk bagi Calon Konselor. Tesis. Tidak Dipublikasikan. Malang: PPS Universitas Negeri Malang

__online). Prefrontal Brain Picture. https://upload.wikimedia.org/wikipedia/commons/a/ab/Prefr ontal_cortex.png diakses 21Nopember 2015

Zemrome. 2012. Mentacognitive Attention Control. (online).http://www.frontiersin.org/files/Articles/58635/fpsyt -04-00173-HTML-r1/image_m/fpsyt-04-00173-g002.jpg. diakses 21 Nopember 2015 